\title{
DELAY IN DIAGNOSIS OF TUBERCULOSIS AMONG UNDER TREATMENT PATIENTS IN RAJSHAHI CITY, BANGLADESH
}

\author{
Chowdhury Md R K ${ }^{1}$, Rahman Md S², Mondal Md N I', Islam Md R ${ }^{1}$, Sayem Md A \\ ${ }^{1}$ Department of Population Science and Human Resource Development, University of Rajshahi, Rajshahi, Bangladesh \\ 2 Department of Public Health, First Capital University of Bangladesh, Chuadanga, Bangladesh \\ ${ }^{3}$ National Tuberculosis Control Program, Directorate General of Health Services, Bangladesh
}

\begin{abstract}
Introduction: Delay in diagnosis regarding Tuberculosis (TB) is common in developing country as well as in Bangladesh. Therefore, the aim of the study is to identify the factors which have effects on delay in diagnosis.

Methodology: A cross-sectional study was carried out at Rajshahi City, Bangladesh. A total of 384 TB patients were took part in the interview presented in the study areas for seeking treatment. The samples were selected using stratified random sampling with simple random sampling techniques. Descriptive statistics, chi-square test and multivariate logistic regression methods in SPSS were employed in this analysis.
\end{abstract}

Results: The results revealed that around $76.3 \%$ patients delay in diagnosis and among them $81.3 \%$ pulmonary patients were found delay. Patients' sex, educational status, area of living, and monthly family income were significantly associated with delay in the diagnosis of TB, as obtained through Chisquare test. Multivariate logistic regression method identified sex, educational status, monthly family income and first visit before diagnosis as risk factors of diagnostic delay.

Conclusion: Massive health education needs to be included in the existing TB control programs to enhance the accessibility of patients in health-care service without delay in diagnosis.

Key words: Tuberculosis, Diagnostic Delay, Socio-demographic Factors, Chi-square Test, Logistic Regression Analysis

\section{INTRODUCTION}

Tuberculosis (TB) is an ancient chronic communicable disease caused by the bacillus Mycobacterium TB (MTB) which spreads from person to person through air. It is the most common cause of infectious disease-related morbidity and mortality worldwide and also one of the top ten causes of global mortality. Reemergence and association with acquired immunodeficiency syndrome (AIDS) have made TB a global threat. ${ }^{1}$

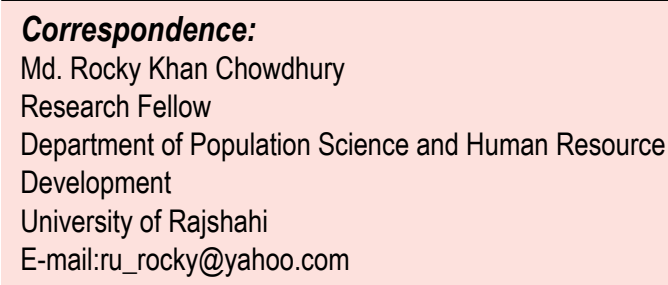

Currently, one third of world's population is infected with MTB resulting in annually approximately 1.8 million deaths worldwide. ${ }^{2}$ TB remains a one of the major causes of morbidity and mortality in Bangladesh. Bangladesh is placed $6^{\text {th }}$ among the 22 TB high burden countries (HBCs) ${ }^{3}$ which focuses the susceptibility of TB in the country. ${ }^{4}$ In 2010, the National TB Control Program (NTP), Bangladesh detected approximately 151,800 TB cases including 105,772 (70\%) new smearpositive cases with case detection rate of $46.0 \%{ }^{2}$ From 1993 onwards, the estimated case detection rate of the NTP has remained below the target of World Health organization (WHO) and diagnostic delay is one of the significant reasons behind this. The time interval from the appearance of the major symptoms of the disease until diagnosis is termed as diagnostic delay, which deteriorates the disease, boost the threat of morbidity and mortality 
and enhance the risk of TB transmission in the community. ${ }^{5,9}$ Early diagnosis of TB and rapid commencement of treatment is essential for an effective TB control program. An infected person who remains undiagnosed and untreated can infect ten to fifteen people every year. ${ }^{10}$

The magnitude and risk factors for diagnostic delays have been well documented in a number of studies. ${ }^{1,11,12}$ Patient's decision on seeking healthcare depends on different factors. ${ }^{13,14}$ In several studies, it has been documented that health seeking behavior, low access to health care facilities, poverty, rural residence, education, female sex, old age are in significant relation with delays in diagnosis. ${ }^{1,5,15,16}$ Therefore, the authors have tried to find out the association between the various socio-demographic factors and delay in diagnosis among TB patients in Bangladesh context. In Bangladesh no recent study was available in this regard. Without identifying the appropriate reasons for diagnostic delay, it is difficult to minimize delay. Therefore, the main purpose of this study is to identify the determinants that affect patients' diagnostic delay for TB.

\section{METHODOLOGY}

\section{Study Areas}

A cross sectional study was carried out at Rajshahi City, Bangladesh. The study sample consists of 384 TB patients (284 pulmonary patients and 100 extra-pulmonary patients) at Rajshahi City, Bangladesh, between June 2011 and February 2012. Samples were selected using stratified random sampling with simple random sampling techniques. The Rajshahi City consists of four Thanas (sub-districts). One health care centre was chosen from each of four Thanas according to the good number of patients' flow. The selected health centers were Rajshahi Chest Disease Clinic (CDC) from Boalia Thana, Chest Disease Hospital (CDH) from Rajpara Thana, Tilottoma (Noudapara Branch) from Shah Mokhdum Thana and Population Service and Training Centre (PSTC) from Motihar Thana of Rajshahi city. All subjects gave their consent before the interview started.

\section{Study Population Selection}

The patients (>14 years old) were taking treatment during the study period were selected for this study. Patients in whom TB was suspected were sent to the laboratory for sputum microscopy and were registered in the TB laboratory. Patients diagnosed with smear positive TB were registered for treatment. Pulmonary TB was diagnosed according to the Guidelines NTP Bangladesh. ${ }^{17}$ The diagnosis of extra-pulmonary TB was based on a combination of clinical, radiological, and histopathological findings. In these selected study sites, TB is diagnosed and treated without charge and the result of the diagnosis was confirmed in the same day.

\section{Survey Instrument, Data Management and Analysis}

The patients were face-to-face interviewed by using a semi-structured interview schedule containing pre-coded and open-ended questions. Required corrections were made following an evaluation of the pilot survey and a final version of the questionnaire was completed. Two trained interviewers and a medical doctor conducted the interviews after obtaining informed consent of the respondent. Patients were informed clearly about the purpose of the study. For each patient, the following information was collected: sex, age, educational status, family income, area of living, type of house, type of patient, first visit before diagnosis and duration of suffering. In this study, diagnostic delay was considered when the time interval between the onset of symptoms and diagnosis was more than three weeks.

Univariate analysis was done to find out the distributions of different items related to diagnostic delay. Cross study comparisons were carried out between diagnostic delay and socio- demographic characteristics. The Pearson's Chi-squared $\left(\chi^{2}\right)$ test for higher contingency tables was used to determine associations between dependent and independent variables. Binary logistic regression analysis was performed to identify the socio-demographic determinants that affect patients' diagnostic delay. The independent variables considered in this study were age, sex, educational status, monthly family income, area of living, type of house, type 
of patients, and first visit before diagnosis. The dependent variable has been classified in the binary logistic regression model as follows:

$$
Y=\left\{\begin{array}{l}
1, \text { ifthe patients delay in diagnosis } \\
0, \quad \text { otherwise }
\end{array}\right.
$$

All statistical analyses were performed using Statistical Package for Social Science (SPSS, version 16).

\section{RESULTS}

\section{Socio-economic and Demographic Characteristics of Patients}

Table 1 represents socio-economic and demographic characteristics of TB patients. Among the selected 384 TB patients, more than

\begin{tabular}{|c|c|c|}
\hline Factors & Frequency & Percent \\
\hline $\begin{array}{l}\text { Sex - Male } \\
\text { Female }\end{array}$ & $\begin{array}{l}225 \\
159\end{array}$ & $\begin{array}{l}58.6 \% \\
41.4 \%\end{array}$ \\
\hline $\begin{aligned} \text { Age }- & <20 \text { years } \\
& 20-35 \text { years } \\
& 36-50 \text { years } \\
& >50 \text { years }\end{aligned}$ & $\begin{array}{l}42 \\
138 \\
122 \\
82\end{array}$ & $\begin{array}{l}10.9 \% \\
35.9 \% \\
31.8 \% \\
21.4 \%\end{array}$ \\
\hline $\begin{array}{l}\text { Educational status } \\
0-5 \text { years of schooling } \\
6-12 \text { years of schooling } \\
>12 \text { years of schooling }\end{array}$ & $\begin{array}{l}202 \\
128 \\
54 \\
\end{array}$ & $\begin{array}{l}52.6 \% \\
33.3 \% \\
14.1 \% \\
\end{array}$ \\
\hline $\begin{array}{l}\text { Monthly family income } \\
\text { (BDT) } \\
\quad<8000 \\
8000-15000 \\
>15000\end{array}$ & $\begin{array}{l}178 \\
88 \\
118\end{array}$ & $\begin{array}{l}46.4 \% \\
22.9 \% \\
30.7 \%\end{array}$ \\
\hline $\begin{array}{r}\text { Area of living - Village } \\
\text { Town }\end{array}$ & $\begin{array}{l}148 \\
236\end{array}$ & $\begin{array}{l}38.5 \% \\
61.5 \%\end{array}$ \\
\hline $\begin{array}{r}\text { Type of house - Clay made } \\
\text { Brick built }\end{array}$ & $\begin{array}{l}165 \\
219\end{array}$ & $\begin{array}{l}43.0 \% \\
57.0 \%\end{array}$ \\
\hline $\begin{array}{l}\text { Type of patients } \\
\text { Extra-pulmonary } \\
\text { Pulmonary }\end{array}$ & $\begin{array}{l}100 \\
284\end{array}$ & $\begin{array}{l}26.0 \% \\
74.0 \%\end{array}$ \\
\hline $\begin{array}{l}\text { First visit before diagnosis } \\
\text { Pharmacy } \\
\text { Public hospital } \\
\text { GO/NGO clinic }\end{array}$ & $\begin{array}{l}79 \\
161 \\
144\end{array}$ & $\begin{array}{l}20.6 \% \\
41.9 \% \\
37.5 \% \\
\end{array}$ \\
\hline $\begin{array}{l}\text { Duration of suffering } \\
\leq 6 \text { months } \\
>6 \text { months }\end{array}$ & $\begin{array}{l}266 \\
118\end{array}$ & $\begin{array}{l}69.3 \% \\
30.7 \%\end{array}$ \\
\hline $\begin{aligned} & \text { Delay in diagnosis - } \text { No } \\
& \text { Yes }\end{aligned}$ & $\begin{array}{l}91 \\
293\end{array}$ & $\begin{array}{l}23.7 \% \\
76.3 \% \\
\end{array}$ \\
\hline Total & 384 & 100 \\
\hline
\end{tabular}

half $(58.6 \%)$ were males, most patients $(67.7 \%)$ were found between ages 20-50 years. About half of the Patients $(52.6 \%)$ had lower level of education (completed 0 to 5 years of education). The higher percentage of TB patients were found among low income group (monthly family income $<8000$ TK) $(46.4 \%)$, town dwellers (61.5\%), whose houseswere brick built (57.0\%). In case of patients type, more than two third were pulmonary patients $(74.0 \%)$ and suffer from $\leq 6$ months $(69.3 \%)$. Also higher percentage of patients $(41.9 \%)$ went to public hospital for seeking healthcare before diagnosis of TB disease. Most of these patients (76.3\%) reported diagnostic delay.

\section{Associations between Diagnostic Delay among TB Patients and Various Socio-demographic Factors}

Table 2 represents the associations between diagnostic delay among TB patients and different socio-demographic factors along with the significant values. The associations were obtained through Chi-square test between diagnostic delay and the socio-demographic factors of the patients. All the variables except age were significantly associated with diagnostic delay among the TB patients. The study results revealed that, $80 \%$ of all male patients reported delayed diagnosis $(>3$ weeks), which was comparatively higher than that of females $(71.1 \%)$. The results also noticed that, diagnostic delays increased with the increase of ages; but it is decreased with the increase of the levels of education. The $69 \%$ of patients aged below 20 years reported diagnostic delay, which has sequentially increased to $80.5 \%$ for patients aged over 50 years. Again, the higher percentage of diagnostic delay (84.7\%) were found among respondents who had completed 0 to 5 years of schooling, but the percentage was lower among respondent who had completed 6 to 12 years of schooling (68.8\%) and above 12 years of schooling $(63.0 \%)$.

Delay in the diagnosis of TB disease was more common among the patients from village area compared to the patients form urban area $(70.3 \%)$. The percentage of patients that experienced diagnostic delay was significantly higher among pulmonary patients (81.3\%) and who lived in clay made house $(84.8 \%)$ compared to extra-pulmonary patients $(62.0 \%)$ and those lived in brick built 


\begin{tabular}{|c|c|c|c|}
\hline \multirow[b]{2}{*}{ Factors } & \multicolumn{2}{|c|}{ Diagnostic delay } & \multirow{2}{*}{$\begin{array}{l}\mathrm{P} \\
\text { values }\end{array}$} \\
\hline & $\begin{array}{l}\text { Not delay } \\
\quad(\leq 3 \\
\text { weeks })\end{array}$ & $\begin{array}{l}\text { Delay } \\
(>3 \\
\text { weeks) }\end{array}$ & \\
\hline $\begin{array}{l}\text { Sex } \\
\qquad \text { Male } \\
\text { Female }\end{array}$ & $\begin{array}{l}45(20.0 \%) \\
46(28.9 \%)\end{array}$ & $\begin{array}{l}180(80.0 \%) \\
113(71.1 \%)\end{array}$ & 0.043 \\
\hline $\begin{array}{l}\text { Age } \\
\qquad 20 \text { years } \\
20-35 \text { years } \\
36-50 \text { years } \\
>50 \text { years }\end{array}$ & $\begin{array}{l}13(31.0 \%) \\
33(23.9 \%) \\
29(23.8 \%) \\
16(19.5 \%)\end{array}$ & $\begin{array}{l}29(69.0 \%) \\
105(76.1 \%) \\
93(76.2 \%) \\
66(80.5 \%)\end{array}$ & 0.570 \\
\hline $\begin{array}{l}\text { Educational } \\
\text { status } \\
0-5 \text { years of } \\
\text { schooling } \\
6-12 \text { years of } \\
\text { schooling } \\
>12 \text { years of } \\
\text { schooling }\end{array}$ & $\begin{array}{l}31(15.3 \%) \\
40(31.2 \%) \\
20(37.0 \%)\end{array}$ & $\begin{array}{l}171(84.7 \%) \\
88(68.8 \%) \\
34(63.0 \%)\end{array}$ & 0.000 \\
\hline $\begin{array}{l}\text { Monthly family } \\
\text { income (BDT) } \\
\quad<8000 \\
8000-15000 \\
>15000\end{array}$ & $\begin{array}{l}22(12.4 \%) \\
26(29.5 \%) \\
43(36.4 \%)\end{array}$ & $\begin{array}{l}156(87.6 \%) \\
62(70.5 \%) \\
75(63.6 \%)\end{array}$ & 0.000 \\
\hline $\begin{array}{l}\text { Area of living } \\
\text { Village } \\
\text { Town }\end{array}$ & $\begin{array}{l}21(14.2 \%) \\
70(29.7 \%)\end{array}$ & $\begin{array}{l}127(85.8 \%) \\
166(70.3 \%)\end{array}$ & 0.001 \\
\hline $\begin{array}{l}\text { Type of house } \\
\text { Clay made } \\
\text { Brick built }\end{array}$ & $\begin{array}{l}25(15.2 \%) \\
66(30.1 \%)\end{array}$ & $\begin{array}{l}140(84.8 \%) \\
153(69.9 \%)\end{array}$ & 0.001 \\
\hline $\begin{array}{l}\text { Type of patients } \\
\text { Extra-pulmonary } \\
\text { Pulmonary }\end{array}$ & $\begin{array}{l}38(38.0 \%) \\
53(18.7 \%)\end{array}$ & $\begin{array}{l}62(62.0 \%) \\
231(81.3 \%) \\
\end{array}$ & 0.000 \\
\hline $\begin{array}{l}\text { First visit before } \\
\text { diagnosis } \\
\text { Pharmacy } \\
\text { Public hospital } \\
\text { GO/NGO clinic }\end{array}$ & $\begin{array}{l}8(10.1 \%) \\
25(15.5 \%) \\
58(40.3 \%)\end{array}$ & $\begin{array}{l}71(89.9 \%) \\
136(84.5 \%) \\
86(59.7 \%)\end{array}$ & 0.000 \\
\hline $\begin{array}{l}\text { Duration of } \\
\text { suffering } \\
\leq 6 \text { months } \\
>6 \text { months }\end{array}$ & $\begin{array}{l}76(28.6 \%) \\
15(12.7 \%)\end{array}$ & $\begin{array}{l}190(71.4 \%) \\
103(87.3 \%)\end{array}$ & 0.001 \\
\hline Total & $91(23.7 \%)$ & $293(76.3 \%)$ & \\
\hline
\end{tabular}

house $(69.9 \%)$ respectively. but diagnostic delay were found nearly same for both patients who went to pharmacy $(89.9 \%)$ and public hospital $(84.5 \%)$ for seeking healthcare before the diagnosis of TB disease. Delay in the diagnosis was more prevalent among the patients who suffered from TB more than 6 months $(87.3 \%)$.

\section{Risk Factors for Delay in Diagnosis of TB among Patients}

Table 3 represents the estimate of relative risks (Odds ratio [OR]) that were calculated for each of the categorical variables, $p$-value, and $95 \%$ confidence interval $(\mathrm{Cl})$ for $\mathrm{OR}$. In this study, the logistic regression model has beenfitted by respondent's age, sex, educational status, monthly family income, area of living, type of house, type of patients, and first visited healthcare center before diagnosis. The result of logistic regression analysis revealed that, sex had significant effect on diagnostic delay. Female patients had about $42 \%$ [OR $=0.582,95 \% \mathrm{Cl}=0.329-1.028]$ lower probability of delayed in diagnosis of TB than male patients. The study result indicated that, educational status had negative and significant effect on the diagnostic delay. The study result showed that education had somewhat significant impact on delay in diagnosis since the $p$ value $(p=0.067)$ was close to the significant level for the patients who completed 6-12 years of schooling. The patients who had completed 6-12 years of schooling had about $52 \%(\mathrm{OR}=0.481,95 \% \mathrm{Cl}=$ $0.220-1.053)$ lower risk of delayed in diagnosis than those of less educated (completed 0 to 5 years of schooling) patients. Again, the patients whose monthly income was $8000-15000$ TK had $64 \%$ less risk (OR $=0.355,95 \% \mathrm{Cl}=0.155-0.811)$ and whose monthly family income was $>15000$ TK had $57 \%$ less risk (OR=0.433, 95\% Cl=0.163-1.152) of having diagnostic delay compared to those having monthly family income below $8000 \mathrm{TK}$. The result also indicated that, the patients who went to $\mathrm{GO} /$ NGO clinic for seeking healthcare before diagnosis of TB had about $80 \%$ less probability [OR $=0.206$, $95 \% \mathrm{Cl}=0.087-0.489]$ of having diagnostic delay compared to those went to pharmacy for seeking health care. 


\begin{tabular}{|c|c|c|c|c|c|}
\hline $\begin{array}{l}\text { Explanatory } \\
\text { variables }\end{array}$ & B & S.E. & WS & $\begin{array}{l}\mathrm{P} \text { - } \\
\text { values }\end{array}$ & OR $(95 \% \mathrm{Cl})$ \\
\hline $\begin{array}{l}\text { Sex } \\
\text { Male (RC) } \\
\text { Female }\end{array}$ & -0.542 & 0.290 & 3.483 & 0.062 & $\begin{array}{l}1.00 \\
0.582(0.329-1.028)\end{array}$ \\
\hline $\begin{array}{l}\text { Age } \\
\quad<20 \text { years }(\mathrm{RC}) \\
20-35 \text { years } \\
36-50 \text { years } \\
>50 \text { years }\end{array}$ & $\begin{array}{l}-0.165 \\
-0.526 \\
-0.287\end{array}$ & $\begin{array}{l}0.439 \\
0.465 \\
0.506\end{array}$ & $\begin{array}{l}0.142 \\
1.280 \\
0.323\end{array}$ & $\begin{array}{l}0.706 \\
0.258 \\
0.570\end{array}$ & $\begin{array}{l}1.00 \\
0.848(0.359-2.003) \\
0.591(0.238-1.470) \\
0.750(0.278-2.021)\end{array}$ \\
\hline $\begin{array}{l}\text { Educational status } \\
0-5 \text { years of schooling } \\
\text { (RC) } \\
6-12 \text { years of } \\
\text { schooling } \\
>12 \text { years of } \\
\text { schooling }\end{array}$ & $\begin{array}{l}-0.732 \\
-0.751\end{array}$ & $\begin{array}{l}0.400 \\
0.496\end{array}$ & $\begin{array}{l}3.350 \\
2.293\end{array}$ & $\begin{array}{l}0.067 \\
0.130\end{array}$ & $\begin{array}{l}1.00 \\
0.481(0.220-1.053) \\
0.472(0.178-1.248)\end{array}$ \\
\hline $\begin{array}{l}\text { Monthly Family } \\
\text { income (BDT) } \\
\quad<8000 \text { (RC) } \\
8000-15000 \\
>15000\end{array}$ & $\begin{array}{l}-1.036 \\
-0.837\end{array}$ & $\begin{array}{l}0.422 \\
0.499\end{array}$ & $\begin{array}{l}6.031 \\
2.811\end{array}$ & $\begin{array}{l}0.014 \\
0.094\end{array}$ & $\begin{array}{l}1.00 \\
0.355(0.155-0.811) \\
0.433(0.163-1.152)\end{array}$ \\
\hline $\begin{array}{l}\text { Area of living } \\
\text { Village (RC) } \\
\text { Town }\end{array}$ & -0.032 & 0.415 & 0.006 & 0.938 & $\begin{array}{l}1.00 \\
0.968(0.430-2.182)\end{array}$ \\
\hline $\begin{array}{l}\text { Type of house } \\
\text { Clay made (RC) } \\
\text { Brick built }\end{array}$ & 0.504 & 0.474 & 1.132 & 0.287 & $\begin{array}{l}1.00 \\
1.656(0.654-4.193)\end{array}$ \\
\hline $\begin{array}{l}\text { Type of patients } \\
\text { Extra-pulmonary (RC) } \\
\text { Pulmonary }\end{array}$ & 0.293 & 0.316 & 0.861 & 0.354 & $\begin{array}{l}1.00 \\
1.340(0.722-2.489)\end{array}$ \\
\hline $\begin{array}{l}\text { First visit before } \\
\text { diagnosis } \\
\text { Pharmacy (RC) } \\
\text { Public hospital } \\
\text { GO/NGO clinic }\end{array}$ & \begin{tabular}{|l|}
-0.487 \\
-1.580 \\
\end{tabular} & $\begin{array}{l}0.444 \\
0.441 \\
\end{array}$ & $\begin{array}{l}1.204 \\
12.854 \\
\end{array}$ & $\begin{array}{l}0.272 \\
0.000 \\
\end{array}$ & $\begin{array}{l}1.00 \\
0.614(0.257-1.467) \\
0.206(0.087-0.489) \\
\end{array}$ \\
\hline Constant & 3.027 & 0.709 & 18.216 & 0.000 & 20.630 \\
\hline
\end{tabular}

were associated with TB delay. ${ }^{20} \mathrm{~A}$ study in South India found longer diagnostic delay among men. ${ }^{21}$ Another study in Nepal summarized that male patients experienced higher diagnostic delay ${ }^{22}$ but several studies in developing countries reported longer diagnostic delay among women. ${ }^{19,23}$ In our study, male patients experienced remarkable delay in diagnosis and constituted the higher percentage as compare to female patients. But the result does not match with other studies which revealed that propensity to make delay was higher among females. $5,16,20,24$

Several studies has highlighted that illiteracy was significantly associated with diagnostic delay. ${ }^{25-27}$ Our study revealed that education is one of the most significant factors that closely associated with delay in diagnosis among patients. Lower educated patients ( $0-5$ years of schooling) constituted the higher number and low level of education has somewhat significant impact on patient's diagnostic delay as well. Diagnostic delay was found low among the higher educated (>12 years of schooling) patients. A qualitative approach at rural area of Tanzania did not

\section{DISCUSSION}

The study showed that TB patients at Rajshahi City, Bangladesh suffer from substantial delays until a diagnosis is made. Respondent's sex, educational status, family income, area of living, types of house, types of patient, first visited healthcare center before diagnosis and duration of suffering are significantly associated with the diagnostic delay of patients. In accordance with other studies $1,5,18,19$ significant association were found among socio-economic factors and patients' diagnostic delay. Studies conducted in Tanzania and Botswana showed that patients from village areas, patients with low education level, site of first visit, lack of TB information and female sex found any patients being higher educated. ${ }^{28}$ The result of present study was consistent with some other studies $5,7,29,30$ as well. Economic barrier frequently causes obstruction for seeking health care facilities. Patients especially from village area, often go far away for seeking health care due to poor diagnostic facility which is sometimes cost ineffective for them that resultant delay in diagnosis. ${ }^{18}$ This study resulted that the patients correspond to comparatively low income group at Rajshahi, found delay in diagnosis of TB. Some previous studies found the same result. $13,18,22$ Among the demographic factors, area of living has been identified significant for the diagnostic delay in this study. The patients' delay in diagnosis varied with the patients' area of residence. In our study, the percentage was higher for the patients of 
rural setting as compared to urban setting. Several studies highlighted that higher percentage of TB patients reported delay corresponded to rural area ${ }^{15,31}$ which was similar to the findings of present study. The delay in diagnosis in rural areas is higher due to low level of knowledge and awareness of the disease, lack of information about availability of free treatment, income and communication constraints of villagers. Delayed diagnosis was documented for both extra-pulmonary and pulmonary TB patientsand it was more prevalent among pulmonary TB patients in the present study. Many authors have found higher diagnostic delay among pulmonary patients. ${ }^{1,5,30}$ But, in accordance with some other studies ${ }^{10,11,16}$ extra-pulmonary TB patients were significantly more likely to have experienced diagnostic delay. However, it is not surprising because, patients with extra-pulmonary TB may have diffuse or non-specific symptoms and are likely to experience longer delays than patients with pulmonary TB in both low and highendemic settings.

Differentstudiesidentified poor access to the NTP as one of the main factors in delayed diagnosis. .,15,23-32 $^{2}$ In this study, the higher percentage of patients went to public hospital for seeking health care, but diagnostic delay were higher among those went to pharmacy at first for seeking health care before the diagnosis. A study in Ethiopia, patients who first visited a qualified medical provider experienced delay before initiation of diagnosis and treatment. ${ }^{32}$ After the onset of symptoms especially the rural people of Bangladesh go to pharmacy or traditional practitioner due to lack of knowledge, financial and communication problems, and sometimes due to negligence of the disease as well as due to poor coverage of NTP. Sometimes these cause delay in diagnosis. A bunches of studies have revealed that selection of a traditional practitioner for the first visit is associated with a prolonged delay in diagnosis. ${ }^{19,23,24,33}$ In this study, two-third of the patients recorded living with TB within 6 months and the percentage that experienced diagnostic delay was higher for the patients who suffered TB for more than 6 months which indicates the vulnerability of diagnostic delay. Several studies were conducted on the new TB patients and found significant delay in diagnosis ${ }^{1,5,8,32}$ and no recent study was found on old TB patients for delay in diagnosis. For the patients, delay in diagnosis and the late start of TB treatment can result in increased severity and mortality. ${ }^{11}$ In our study, multivariate analysis has noticed that lack of education, poor income, pulmonary TB are the risk factors for diagnostic delay which is supported by the other studies. 5,16,18

\section{Limitation of the Study}

There were several limitations to our study. Firstly, TB patients aged below 14 years were not included in this study. Because all the patients below 14 years of age were found children during the study period and the information were collected for the study was not enough to study the child patient's delay in diagnosis. Some other variables are essential along with the present information to serve the purpose. Further research should be conducted on the concern issue precisely. Secondly, only four healthcare centers at Rajshahi city were selected for this study. The sample size was relatively small but they were adequate for evaluating requisite purpose.

\section{DISCUSSION}

This study demonstrated that some sociodemographic factors have significant effects on delay in diagnosis of patients. Patients' sex, educational status, family income, area of living, type of house, type of patients, first visit before diagnosis and duration of suffering are significantly associated with diagnostic delay. Significant delay was found among the patients of low educated and lower income group. The patients who first visited public and private hospitals found delay in diagnosis. The multivariate analysis illustrated that patient who first visits pharmacy experienced delay in diagnosis. Therefore, it is important to facilitate prompt utilization of the health services by raising public awareness about the disease. Also, the existing TB control programs need to be modified and massive health education system need to be included in the existing TB control programs.

Acknowledgements: The authors are gratefully acknowledged the extreme cooperation received from the TB patients and staffs of the TB centers as well as to the authorities of National TB program, Bangladesh for their kind permission to collect the data and necessary information from the TB patients. The authors are very grateful to the Department of Population Science and Human 
resource Development, University of Rajshahi; Bangladesh where the research works has been performed.

\section{REFERENCES}

1. Saqib M, Awan I, Rizvi S, Shahzad M, Mirza Z, Tahseen S, et al. Delay in diagnosis of tuberculosis in Rawalpindi, Pakistan. BMC research notes. 2011;4:165.

2. Programme GT. Global tuberculosis control: WHO report: Global Tuberculosis Programme, World Health Organization; 2010.

3. Banu S, Mahmud AM, Rahman MT, Hossain A, Uddin MKM, Ahmed T, et al. Multidrug-resistant tuberculosis in admitted patients at a tertiary referral hospital of Bangladesh. PloS one. 2012;7:40545.

4. Zaman K. Tuberculosis: a global health problem. Journal of health, population, and nutrition. 2010;28:111.

5. Demissie M, Lindtjorn B, Berhane Y. Patient and health service delay in the diagnosis of pulmonary tuberculosis in Ethiopia. BMC Public Health. 2002;2:23.

6. Ford CM, Bayer AM, Gilman RH, Onifade D, Acosta C, Cabrera L, et al. Factors associated with delayed tuberculosis test-seeking behavior in the Peruvian Amazon. The American journal of tropical medicine and hygiene. 2009;81:1097.

7. Gele AA, Bjune $\mathrm{G}$, Abebe F. Pastoralism and delay in diagnosis of TB in Ethiopia. BMC Public Health. 2009;9:5.

8. Odusanya OO, Babafemi JO. Patterns of delays amongst pulmonary tuberculosis patients in Lagos, Nigeria. BMC Public Health. 2004;4:18.

9. Lugga MCL, Muita M, Matiru V, Muchiri E. Factors associated with patient and health service delays in the management of TB in Central Equatoria State in 2008. South Sudan Medical Journal. 2011;4:83-5.

10. Silva DR, Müller AM, Dalcin PdTR. Factors associated with delayed diagnosis of tuberculosis in hospitalized patients in a high TB and HIV burden setting: a cross-sectional study. BMC Infectious Diseases. 2012;12:57.

11. Farah MG, Rygh JH, Steen TW, Selmer R, Heldal E, Bjune G. Patient and health care system delays in the start of tuberculosis treatment in Norway. BMC infectious diseases. 2006;6:33.
12. Goel K, Kondagunta N, Joycee Soans S, Ramachandra Bairy A, Goel P. Reasons for patient delays \& health system delays for Tuberculosis in South India. Indian Journal of Community Health. 2012;23:87-9.

13. Fatiregun A, Ejeckam C. Determinants of patient delay in seeking treatment among pulmonary tuberculosis cases in a government specialist hospital in Ibadan, Nigeria. Tanzan J Health Res. 2010;12.

14. Long NH, Johansson $\mathrm{E}$, Lonnroth $\mathrm{K}$, Eriksson B, Winkvist A, Diwan V. Longer delays in tuberculosis diagnosis among women in Vietnam. The International Journal of Tuberculosis and Lung Disease. 1999;3:388-93.

15. Wondimu T, Kassahun W, Getachew S. Delay in initiating tuberculosis treatment and factors associated among pulmonary tuberculosis patients in East Wollega, Western Ethiopia. Ethiopian Journal of Health Development. 2007;21:148-56.

16. Storla DG, Yimer S, Bjune GA. A systematic review of delay in the diagnosis and treatment of tuberculosis. BMC public health. 2008;8:15.

17. Programme TC. National Guidelines and Operational Manual for Tuberculosis Control. National Tuberculosis Control Programme, Directorate General of Health Services, Ministry of Health and Family Welfare Dhaka, Bangladesh. 2010(Fourth Edition).

18. Güneylioglubdefg D, Yilmazabcdefg A, Bilginbdf S, Bayrambf Ü, Akkayaace E. Factors affecting delays in diagnosis and treatment of pulmonary tuberculosis in a tertiary care hospital in Istanbul, Turkey. Med Sci Monit. 2004;10:67.

19. Needham DM, Foster SD, Tomlinson G, GodfreyFaussett P. Socio-economic, gender and health services factors affecting diagnostic delay for tuberculosis patients in urban Zambia. Tropical Medicine \& International Health. 2001;6:256-9.

20. Ngadaya E, Mfinanga G, Wandwalo E, Morkve 0 . Delay in tuberculosis case detection in Pwani region, Tanzania. A cross sectional study. BMC health services research. 2009;9:196.

21. Rajeswari $R$, Chandrasekaran V, Suhadev $M$, Sivasubramaniam S, Sudha G, Renu G. Factors associated with patient and health system delays in the diagnosis of tuberculosis in South India. Int $\mathrm{J}$ Tuberc Lung Dis 2002;6:789-95.

22. Basnet R, Hinderaker SG, Enarson D, Malla P, Mørkve O. Delay in the diagnosis of tuberculosis in Nepal. BMC Public Health. 2009;9:236. 
23. Yamasaki-Nakagawa M, Ozasa K, Yamada N, Osuga K, Shimouchi A, Ishikawa N, et al. Gender difference in delays to diagnosis and health care seeking behaviour in a rural area of Nepal. Int $\mathrm{J}$ Tuberc Lung Dis 2001;5:24-31.

24. Huong NT, Vree M, Duong BD, Khanh VT, Loan VT, Borgdorff MW, et al. Delays in the diagnosis and treatment of tuberculosis patients in Vietnam: a cross-sectional study. BMC Public Health. 2007;7:110.

25. Madebo T, Lindtjorn B. Delay in treatment of pulmonary tuberculosis: an analysis of symptom duration among Ethiopian patients. MedGenMed: Medscape general medicine. 1999:E6-E.

26. Mesfin MM, Newell JN, Walley JD, Gessessew A, Madeley RJ. Delayed consultation among pulmonary tuberculosis patients: a cross sectional study of 10 DOTS districts of Ethiopia. BMC Public Health. 2009;9:53.

27. Mesfin MM, Tasew TW, Tareke IG, Kifle YT, Karen WH, Richard MJ. Delays and care seeking behavior among tuberculosis patients in Tigray of northern Ethiopia. Ethiopian Journal of Health Development. 2005;19:7.

28. Verhagen L, Kapinga R, van Rosmalen-Nooijens K. Factors underlying diagnostic delay in tuberculosis patients in a rural area in Tanzania: a qualitative approach. Infection. 2010;38:433-46.
29. Qureshi SA, Morkve O, Mustafa T. Patient and health system delays: health-care seeking behaviour among pulmonary tuberculosis patients in Pakistan. JPMA The journal of the Pakistan Medical Association. 2008;58:318.

30. Bawankule S, Quazi S, Gaidhane A, Khatib N. Delay in DOTS for new pulmonary tuberculosis patient from rural area of Wardha District, India. Online Journal of Health and Allied Sciences. 2010;9.

31. Ayuo P, Diero L, Mwangi A. Causes of delay in diagnosis of pulmonary tuberculosis in patients attending a referral hospital in Western Kenya. East African Medical Journal. 2008;85:263-8.

32. Yimer S, Bjune G, Alene G. Diagnostic and treatment delay among pulmonary tuberculosis patients in Ethiopia: a cross sectional study. BMC Infectious Diseases. 2005;5:112.

33. Xu B, Jiang $Q$, Xiu Y, Diwan V. Diagnostic delays in access to tuberculosis care in counties with or without the National Tuberculosis Control Programme in rural China. The International Journal of Tuberculosis and Lung Disease. 2005;9:784-90. 